\title{
KORELASI LANDASAN TEOLOGIS DAN FILOSOFIS DALAM PENGEMBANGAN PRINSIP DAN PRAKSIS PENDIDIKAN AGAMA KRISTEN
}

\author{
Dyulius Thomas Bilo \\ Sekolah Tinggi Teologi Injili Arastamar (SETIA) Jakarta \\ greatshine@sttsetia.ac.id
}

\begin{abstract}
ABSTRAK
Pendidikan Agama Kristen diletakkan atas bebarapa landasan utama dua diantaranya adalah landasan teologis dan landasan filosofis. Kedua Fondasi Ini sangat berkorelasi merumuskan dan mengembangkan prinsip dan praksis Pendidikan Agama Kristen. Sangat penting meletakkan dasar teologi dan filsafat kristiani dalam mengikis pandangan sekuler dan liberalisme dalam dunia pendidikan yang sangat kuat pengaruhnya bagi prinsip iman dan praksis PAK seperti penekanan pada otonomisasi rasio, pengalaman dan kemampuan manusia dibanding dengan otoritas Allah dan firman-Nya. Artikel ini menekankan pentingnya memahami korelasi landasan teologis dan filosofis dalam perumusan dan pengembangan prinsip dan praksis PAK. Penelitian ini dilaksanakan di Sekolah Tinggi Teologi Injili Arastamar (SETIA) Jakarta dengan mengunakan metode penelitian kepustakaan dengan mengumpulkan data atau teori dari berbagai sumber, dianalisis dan dieksplorasi serta diberikan kesimpulan dengan penulis sebagai instrumen utamanya. Penelitian ini dilaksanakan pada bulan Mei-Juni 2020. Temuan penelitian ini adalah mengenal korelasi Filsafat dan Teologi dalam PAK, mengetahui Landasan Filosofis PAK. Mengenal metafisika, epistemologi, dan aksiologi dalam Pendidikan Kristen, mengetahui integrasi iman dan ilmu dalam prinsip dan praksis PAK.
\end{abstract}

Kata Kunci: Teologi; Filsafat, Iman, Alkitab; Pendidikan; Agama; Kristen.

\section{PENDAHULUAN}

Dunia terus mengalami dinamika kehidupannya sesuai dengan tantangan pada zamanya. Filsafat umum dan filsafat kristiani juga selalu berakselerasi dengan dunia nyata dari waktu ke waktu. Buah-buah pemikiran yang konstruktif akan menjadi ladang dan persemaian yang subur bagi rasio yang sedang berjuang menganalisa kehidupan dan buah-buahnya yang dapat dijadikan warisan dari zaman ke zaman. Segala perspektif yang mendekati kebenaran hakiki akan terpelihara bahkan akan mengalami proses pembersihan, peremajaan, dan pematangan, sementara buah-buah pikiran yang tak memiliki dasar kebenaran akan larut, terhempas dan terhilang dari derasnya arus pemikiran baik sekuler maupun yang kristiani. 
Betapa pentingnya meletakkan dasar yang kuat khususnya bagi pendirian dan pengembangan prinsip dan praksis filosofis pendidikan Kristen. Tatkala filsafat sekuler meletakan dasar pada rasio dan pengalaman yang terbatas dan telah distorsi oleh dosa, spekulasi, kemunafikan serta kebodohan manusia, filsafat kristian terus menjadi garam dan terang serta marcusuar yang tegak berdiri karena diletakkan pada sang pemilik dan sumber pengetahuan dan hikmat itu sendiri, yaitu Allah. Untaian prinsip-prinsip dan praksis-praksis pendidikan menjadi pesona indah dan menggiurkan menarik daya nalar dan rasio untuk menggali dan mengembangkannya karena semuanya itu diperoleh dari rumusan-rumusan teologi yang dapat dipertanggungjawabkan metodologinya secara historis-kritis melalui penelaahan dan penafsiran Alkitab yang begitu bertanggung jawab dari sisi metodologi dan ilmu penafsirannya.

Bangunan-bangunan teologi itu, menjadi ciri yang mencolok di setiap zaman dan masanya, tetapi pada satu prinsip yang tak berubah adalah terletak pada otoritas Alkitab yang diterima sebagai firman Allah. Isi, tujuan, dan metode serta komponen-komponen lainnya dari pendidikan dan pembelajaran secara kristiani akan terus mengalami pembaruan yang dinamis dan membuahkan hasil yang maksimal apabila para pelaku pendidikan menaklukkan pikiran pada pribadi dan karya Kristus sebagai finalitas dari pendidikan Kristen.

\section{METODE PENELITIAN}

Metode yang digunakan dalam penelitian ini adalah menggunakan metode penelitian kualitatif dengan pendekatan studi literatur. Menurut Creswel penelitian studi literatur adalah kajian yang tertulis secara ringkas mengenai artikel dan buku serta dokumen lain yang berhubungan dengan apa yang diteliti melalui mendeskripsikan secara informal teori tersebut secara lengkap dan utuh. Dalam melakukan kajian tersebut, maka diperlukan tahapan-tahapan, yakni: Pertama, mengumpulkan data-data dari berbagai sumber seperti buku-buku, jurnal, internet dan lain-lain yang bertalian dengan topik yang diteliti, kedua dengan mengkaji, membandingkan dan menganalisis berbagai informasi dan teori, memberikan kesimpulan terhadap kajian yang dilakukan untuk memberikan gambaran tentang korelasi landasan teologis dan filosofis dalam perumusan dan pengembangan Pendidikan Agama Kristen.

\section{HASIL DAN PEMBAHASAN}

\section{Filsafat dan Teologi Dalam Pendidikan Agama Kristen}

Menurut Khoe Yao Tung kata filsafat atau philosophy berasal dari kata Yunani yang terdiri dari aka kata philein yang berarti cinta dan Sophia yang berarti kebijaksanaan. Secara etimologi, filsafat bisa berarti mencintai atau mencari kebijaksanaan. Cabangcabang dari filsafat pada umumnya dibagi menjadi tiga bagian besar, yaitu metafisika (aspek kosmologi, teologi, antropologis, dan ontologis), epistemologi (sumber pengetahuan berupa panca indra, wahyu, otoritas, dan intuisi), dan aksiologi (aspek etika dan estetika). ${ }^{1}$ Pemaparan lain bahwa secara etimologi "filsafat" yang merupakan padanan kata "falsafah" dari bahasa Arab dan "philosophy" dari bahasa Inggris berasal dari kata Yunani "philosophia". Kata philosophia merupakan kata majemuk yang terdiri dari kata "philos" dan "sophia", istilah "philos" artinya kasih, bisa juga berarti sahabat.

\footnotetext{
${ }^{1}$ Khoe Yao Tung, Filsafat Pendidikan Kristen: Meletakkan Fondasi dan Filosofi Pendidikan Kristen di Tengah Tantangan Filsafat Dunia (Yogyakarta: Andi,2013), 3
} 
Adapun "sophia" berarti kebijaksanaan atau kearifan atau pengetahuan. Jadi secara hurufiah "philosophia" mencintai kebijaksanaan sahabat pengetahuan. ${ }^{2}$

Alkitab adalah sumber pengetahuan bagi orang-orang percaya. Alkitab menuntun seseorang untuk mencintai hikmat dan mencintai pribadi yang memberikan hikmat yaitu Allah. Filsafat kristiani bukan hanya memandu seorang percaya "cinta akan hikmat" tetapi juga mencintai sang pemberi hikmat sejati. Pazmino mengatakan bahwa orang Kristen selalu diingatkan dalam Kitab Suci bahwa Tuhanlah yang memberikan hikmat, dari mulut-Nya datang pengetahuan dan kepandaian (Ams. 2:6), dan bahwa takut akan Tuhan adalah awal dari pengetahuan atau hikmat (Ams.1:7; 9:10). Suatu klaim yang menakjubkan adalah dalam Kristus tersembunyi segala rahasia hikmat dan pengetahuan (Kol.2:3). ${ }^{3}$

Menurut John Chaffee, mendefinisikan filsafat tidak terlepas dari empat aspek penting, yaitu: (1) Aspek wonder (keheranan), mempelajari filsafat karena keheranan, pertanyaan akan sesuatu yang ada atau terjadi. (2) Aspek Wisdom (kebijaksanaan), mempelari filsafat karena mencari esesni dari sesuatu, mencari kebenaran, dan mencintai kebijaksanaan. (3) Aspek truth (kebenaran), belajar filsafat karena mengarah pada ilmu yang mempertimbangkan kebenaran-kebenaran yang hakiki. (4) Aspek a dynamic process (proses yang dinamik), mempelajari filsafat berawal dari proses, dari runtutan konflik opini-opini, dan terus menerus sampai memperoleh jawaban yang memuaskan. ${ }^{4}$

Menurut Imanuel Kant ada empat masalah pokok yang ingin dipecahkan oleh filsafat: ${ }^{5}$ Pertama, apa yang dapat saya harapkan (was darf hoffen?) pertanyaan ini mengandung makna "hakikat hidup ini" dan keyakinan bahwa manusia masih memiliki harapan yang baik setelah meninggalkan dunia yang fana ini. Permasalahan ini dikupas dalam cabang filsafat metafisika (meta $=$ dibalik dan filsafat $=$ yang nampak). Kedua apakah yang dapat saya ketahui (was kann ich wissen)? Pertanyaan ini ingin mengungkapkan masalah kebenaran yaitu sejauh mana pengetahuan saya itu benar. Dari mana asal dan sumber pengetahuan serta apakah kebenaran itu? Permasalahan ini dikupas dalam cabang filsafat Epistemologi (episteme = penegtahuan). Ketiga, apa yang harus saya perbuat (was sool ich tun)? Pertanyaan ini ingin mengungkapkan masalah pedoman hidup, norma-norma yang berlaku dan nilai-nilai. Permasalahan ini dikupas dalam cabang filsafat Aksiologi (axios = nilai). Dan keempat, apakah manusia itu (was ist der mensch)? Pertanyaan ini ingin mengungkapkan masalah pokok dalam filsafat yaitu tentang hakikat manusia. Permasalahan ini dikupas dalam cabang filsafat manusia (antropologi filsafat $=$ manusia dipandang dari sudut filsafat).

Pemikiran-pemikiran di atas menjadi dasar worldview membicarakan fisafat termasuk filsafat Pendidikan Kristen. Arthur Holmes, seorang filsuf Kristen mendiskripsikan sebuah cara pandang kristiani dengan ciri-ciri sebagai berikut: (1) mempunyai tujuan yang holistik yang berusaha melihat seluruh area kehidupan dan pemikiran secara integratif; (2) menggunakan pendekatan yang memberikan suatu perpektif, dengan cara menilai segala sesuatu berdasarkan cara pandang yang sudah dianut seseorang sebelumnya dengan tujuan untuk memperoleh suatu kerangka berpikir yanh integratif; (3) menyajikan suatu proses yang eksploratif, dengan cara menyelidiki hubungan satu area kehidupan dengan area lainnya dari perspektif yang utuh; (4) bersifat pluralistik sehingga perspektif dasar yang sama bisa diartikulasikan dengan berbagai cara yang berbeda-beda; dan (5) menunjukkan hasil berupa tindakan,

\footnotetext{
${ }^{2}$ Jan Hendrick Rapar, Pengantar Filsafat (Yogyakarta: Kanisius, 1996), 14

${ }^{3}$ Robert W. Pazmino, Fondasi Pendidikan Kristen (Jakarta: BPK. Gunung Mulia, 2012), 111

${ }^{4}$ John Chaffee, The Philosopher's Way, third edition (Boston:Pearson, 2011), 6

${ }^{5}$ Dyulius Thomas Bilo, Bahan Ajar: Filsafat Pendidikan Agama Kristen (Jakarta: STT SETIA, 2018), 4
} 
yang dihasilkan dari apa yang kita pikirkan, apa yang kita nilai berharga dan apayang akan kita lakukan. ${ }^{6}$

Dirk Roy Kolibu mengutip pemikiran Waren S. Benson dari buku "Introducing Christian Education" menjelaskan tentang jenjang atau hirarki filsafat Kristen didasari oleh teologi sistematik. ${ }^{7}$ Pemikiran Benson didasarkan pada pendapat Norman DeJong yang memberikan jenjang filsafat Kristen, yakni dasar otoritas, hakikat manusia, tujuan dan sasaran, organisasi struktural, implementasi, dan evaluasi. Pertama dan terpenting adalah dasar otiritas adalah Kitab Suci. Firman Tuhan adalah kerangka referensi utama dari pendidikan Kristen. Suatu pandangan yang sesuai dengan pandangan Kristus tentang Alkitab. Yesus berkata: "Karena Aku berkata kepadamu: Sesungguhnya selama belum lenyap langit dan bumi ini, suatu iota atau satu titik pun tidak akan ditiadakan dari hukum Taurat, sebelum semuanya terjadi." (Mat.5:18). Dalam Yohanes 10:35 Juruselamat mengatakan "Kitab Suci tidak dapat dibatalkan." Dan dalam Yohanes 17:17, "Kuduskanlah mereka dalam kebenaran, firman-Mu adalah kebenaran.". Kedua, adalah hakikat manusia. Apa dan siapakah manusia, yang dituliskan oleh Kitab Suci. Ketiga, tujuan dan sasaran, didasarkan pada teologi yang memberikan arah, tujuan dan sasaran yang akan dicapai. Keempat hingga keenam adalah organisasi, struktural, implementasi dan evaluasi. ${ }^{8}$

Pendidikan Agama Kristen harus mengembangkan filsafat dan teologi sebagai upaya mengemukakan kebenaran Alkitab tentang berbagai isu kehidupan. Kebenaran sejati (the true truth) bersumber dari Tuhan yang dinyatakan dalam wahyu-Nya: Wahyu umum dan wahyu khusus. Melalui wahyu umum kita melihat kebenaran Allah melalui alam semesta, hati nurani, dan sejarah hidup manusia, suku dan bangsa). Melalui wahyu khusus kebenaran Allah dinyatakan dalam diri Kristus, Alkitab, dan Roh Kudus. Tentu kebenaran itu dinyatakan dalam pelbagai cara (Ibr. 1:1-2). Kebenaran Allah juga dinyatakan dalam kata, ide, dan berbagai peristiwa. Tugas pendidik dan teolog Kristen adalah mencari dengan semboyan "all truth is God truth wherever they may be found." Walaupun kita sadari juga bahwa manusia dalam segala keterbatasannya karena dosa tentu terbatas memperoleh dan memahami kebenaran itu. Keterbatasan itu membuat manusia menderita dan sakit. Holmes menjelaskan "All truth is God truth" bahwa manusia saat ini menderita dengan tiga alasan penting: Manusia kehilangan fokus kebenaran, manusia kehilangan keuniversalan kebenaran, dan manusia kehilangan kesatuan kebenaran. Kebenaran ini setelah ditelaah oleh filsafat kristiani harus dipraktikkan dalam kehidupan sehari-hari. Seperti pendapat Sokrates, bahwa tanpa upaya (cinta) untuk memahami (memiliki) kebijaksanaan, hidup ini tiada arti, "tanpa usaha untuk memahaminya, kehidupan ini tidak ada artinya". Plato dan Aristoteles menggubah pendapat klasik ini, yakni "mengetahui kebaikan (terutama kebenaran) adalah untuk melakukannya." 9

Dari penjelasan di atas, para pendidik Kristen seyogianya mampu merumuskan filsafat pendidikan Kristen yang dapat mengarahkan para peserta didik dan pembaca memahaminya. Brown sangat tegas mengatakan bahwa filsafat Kristen sangat peduli tentang realitas dan kebenaran Allah. Bagi orang Kristen, Allah adalah sumber kebenaran dan realitas, membicarakan filsafat Kristen harus selalu berhubungan

\footnotetext{
${ }^{6}$ Arthur F. Holmes, ed.., The Making of a Christian Mind: A Christian World View and the Academic Enterprise (Downer Grove, IL: InterVasity, 1985), 17

${ }^{7}$ Dirk Roy Kolibu, Bahan Ajar: Teologi Pendidikan Agama Kristen (Jakarta: Pascasarjana UKI, 2020),

99

${ }^{8}$ Norman DeJong, Education in the Truth (Nutley, NJ: Presbyterian\&Reformed, 1974), 61-63

${ }^{9}$ Norman L. Geisler dan Paul D. Feinberg, Filsafat Dari Perpektif Kristiani (Malang: Gandum Mas, 2002), 12
} 
manusia dengan Allah pencipta/penebus. ${ }^{10}$ Bagian menjadi jelas melalui penegasan "the role of scripture...The core of Christian faith is the confidence tha our Creator Gpd is, that He has acted in Christ Jesus to redeem, and that He has revealed both Himself and Truth to us in the written Word." 11

Itulah sebabnya usulan definisi DeJong yang dikutip Robert W. Pazmino dapat dijadikan sebagai referensi dalam merumuskan filsafat pendidikan Kristen, yaitu "suatu usaha untuk menyusun secara sistematis beberapa pemikiran tentang pendidikan ketika diberikan makna berdasarakan pengajaran yang alkitabiah yang menyatakan iman Kristen yang ortodoks." Menjadi tantangan tersendiri bagi pendidik kristiani untuk menyusun formula pendidikan Kristen yang alkitabiah dan terus sikap yang berkomitmen pada otoritas Alkitab. ${ }^{12}$

\section{Landasan Filosofis Pendidikan Agama Kristen}

Fondasi filosofi dikaitkan dengan fondasi Alkitab dan teologi, akan memberikan dasar-dasar universal yang bersifat transcultural dan kultural dalam rangka memandu pola pikir dan praktek pendidikan Kristen. ${ }^{13}$ Menarik kaitan antara fondasi Alkitab, fondasi teologi, dan fondasi filosofi dari pemikiran Charlotte Mason, dikatakan bahwa "sebagaimana aliran air tidak bisa naik lebih tinggi daripada sumbernya, maka tidak akan ada upaya pendidikan apa pun yang bisa melampaui seluruh skema dari pemikiran asal mulanya."14 Bagi Mason, pendidikan adalah buah dari akar filosofinya yang didasarkan dari Alkitab dan teologi. Bagi Pazmino menjadi tantangan bagi pendidik Kristen adalah menyusun suatu filosofi pendidikan yang bersifat eksplisit dan konsisten dengan cara pandang kristiani sementara tetap memberi tempat bagi terjadinya pradoks. ${ }^{15}$

Koe Yao Tung menjelaskan bahwa berkenaan dengan hubungan filsafat dan teologi Kristen mengatakan bahwa pendidikan Kristen adalah pendidikan yang berpusat pada Tuhan, suatu implikasi dalam interpretasi kasih Tuhan. Berkhof dan Van Till mengatakan pendidikan Kristen menggunakan filsafat teistik yang berlandaskan pada kebenaran firman Tuhan (teologi) dan jelas berbeda dengan filsafat pendidikan sekuler. ${ }^{16}$ Menurut Gordon Brown, tujuan pendidikan Kristen berhubungan langsung dengan tujuan hidup orang Kristen itu sendiri yaitu bagi Tuhan dan kemuliaan-Nya. Maka pendidikan dipandang sebagai sarana yang digunakan Roh Kudus untuk membawa peserta didik kepada persekutuan dengan Tuhan, bagi hidup dalam kekekalan. Pendidikan Kristen diperuntukan pada pengembangan pemikiran dalam perspektik Kristen dan untuk melatih mereka dalam kehidupan yang taat sehingga mereka dapat memenuhi tujuan Tuhan bagi keseluruhan hidup. ${ }^{17}$ Oleh sebab itu, sentralitas Alkitab memainkan peranan dan fokus dari filsafat pendidikan Kristen. Terdapat lima titik berangkat untuk memahami filsafat pendidikan Kristen, yakni: Realitas ciptaan Tuhan, mandat penciptaan, mandat budaya, perjanjian, dan mandat

\footnotetext{
${ }^{10}$ Colin Brown, Philosophy and the Christian Faith (London: InterVarsity, 1973), 288

${ }^{11}$ Lawrance O.Richrads, A Theology of Christian Education (Grand Rapid, Michigan: Zondervan Publishing House, 1975), 309

${ }^{12}$ Pazmino, Fondasi Pendidikan Kristen, 112

${ }^{13}$ Pazmino, Fondasi Pendidikan Kristen, 110

${ }^{14}$ Charlotte Manson, Home School Education,Home Education Series Vol.8,edisi 6 (Oxford:Scrivener, 1953), ix

${ }^{15}$ Pazmino, Fondasi Pendidikan Kristen, 110

${ }^{16}$ Louis Berkhof dan Chornelius Van Til, Foundation of Christian Education, terjemahan ketiga (Surabaya: Momentum, 2010), 15

${ }^{17}$ Paul A. Knienel, Gibbs Ollie E. and Berry Sharom E, editors, Philosophy of Christian School Education (Colorado: ACSI Publisher, 1982), 137
} 
Amanat Agung. ${ }^{18}$ Mengapa menggunakan pendekatan filsafat bukan murni teologi saja?. Hal ini tidak mudah memahami dan menjawabnya. Samuel Sidjabat melihat sifat dan model filsafat pendidikan aman menolong memberi pemahaman tentang kebijakan serta pelaksanaan pendidikan dan pembelajaran, yakni dimulai dari sifat filsafat hidup, filsafat pendidikan, kebijaksanaan dan praktik pendidikan, dan kegiatan belajar mengajar. Dari ketiga sifat dasar ini, filsafat merupakan pencarian akan kebenaran yang dimulai dari mengajukan pertanyaan-pertanyaan tentang makna dan tujuan hidup yang hakiki (the ques of life).

Dalam konteks pendidikan, filsafat sering dibicarakan para ilmuwan berkaitan dengan ilmu pengetahuan (sains), walaupun filsafat tidak identik dengan ilmu pengetahuan. Young dalam "A Christian Approach To Philosophy" menjelaskan bahwa filsafat berupaya mengintegrasikan berbagai informasi yang ditemukan oleh sains, khususnya ilmu-ilmy fisika, menerapkan pendekatan analisis, sedangkan filsafat menempuh pendekatan sinotip (integratif-sintesis) dalam kegiatan berpikir. Sains memutuskan perhatiannya kepada penelitian dan penemuan data factual (empiris),sedangkan filsafat tertarik kepada usaha mencari dan mengemukakan makna dan prinsip kerja yang ditempuh serta dari data yang tersedia. Young sangat jelas memposisikan ilmuan adalah penemu (discoverer) sedangkan filosof adalah penafsir (intepreter), namun diakuinya bahwa juga tidak murni karena ilmuwan memerlukan pendekan filosofis dalam memahami ilmu pengetahuan sehingga lahirlah filsafat ilmu pengetahuan.

Harus diakui bahwa teologi dan filsafat berbeda, namun tidak dapat dipisahkan. Van Peursen dalam "Orientasi di Alam Filsafat" melihat relasi filsafat dan teologi dari dua sudut pandang, yakni Barat dan Timur. Di Timur (Asia) filsafat berkembang dalam konteks religious, sedangkan di Barat, agama (konsep-konsep teologis) berkembang dalam konteks filsafat (perenungan). Karena itulah dalam konteks Barat, jika kita belajar teologi, filsafat teologi (filsafat agama) merupakan bidang studi yang mendapat perhatian penting. Bagi Van Peursen pendekatan teologi berkaitan dengan filsafat, Timur lebih ke konteks keagamaan, dan Barat lebih kepada konteks filsafat.

Bagi Nico Syukur dalam karyanya "Filsafat Agama Kristen mengakui bahwa teologi sebagai pengetahuan adikodrati yang metodis, sistematis, dan koheren, tentang apa yang diwahyukan Tuhan. Bisa dikatakan bahwa teologi adalah refleksi "ilmiah" tentang iman. Dasarnya adalah wahyu Tuhan, yang menyatakan diri secara adikodrati.

Berteologi dan berfilsafat dalam konteks panggilan umat Kristen dan pendidikan Kristen adalah panggilan dalam memperkaya pikiran dan wawasan cara berpikir secara komprehensif. Arhur Holmes dalam "Philosophy A Christian Perspectives" gaya berpikir filosofis seperti berpikir sistematis, sintesis, deskriptif, dan normatif dalam memenuhi panggilan hidup kekristenan sangatlah berguna untuk membuat kita lebih efektif. Filsafat dapat lebih memperkaya pemikiran teologi dan upaya berteologi (worldviewish theology) kita sendiri. Kemudian filsafat dapat mendorong kita dalam berapologetika dengan mengemukakan perspektif dan memberikan jawaban yang jelas (clarity) tentang berbagai isu yang muncul serta menantang, diterangi oleh Roh Kudus dan firman Tuhan (1 Pet. 3:15).

Filsafat pendidikan kristiani tidak dapat dilepaskan dari filsafat pendidikan gerejawi. Pelayanan pendidikan hendaknya menjadi domain dan core dari pelayanan gereja. Filosofi ini akan melahirkan energy baru dalam pelayanan gerejawi melebihi pelayanan-pelayanan konvensional yang dijalankan selama ini. Rex E. Johnson mendefinisikkan filosofis berdasarkan kamus Webster yaitu "sebuah analisis atas dasar dan konsep yang mengekspresikan kepercayaan fundamental”. Jika dikaitkan dengan

${ }^{18}$ Tung, Filsafat Pendidikan Kristen, 265-268 
pelayanan, maka pertanyaan sebagai pengarah adalah apakah dasar kepercayaan anda tentang pelayanan?, ketika kita melayani, kita sedang memainkan sebuah filosofi pelayanan. Menurutnya ada delapan keuntungan dari gereja-gereja yang telah meletakkan dasar filosofinya dengan benar, ${ }^{19}$ yakni: (1) dapat menentukan lingkung pelayanannya; (2) dapat secara terus menerus mengevaluasi ulang pengalaman kelompoknya dalam pengertian pesan-nya; (3) dapat mengevaluasi pelayanannya berdasarkan kriteria yang dipertimbangkan masak-masak, bukan atas dasar popularitas suatu program; (4) dapat lebih mungkin mempertahankan pelayanannya tetap seimbang dan fokus pada apa yang penting; (5) dapat memobilisasi proporsi sebagian besar jemaatnya menjadi pendeta; (6) dapat menentukan keuntungan relatif dari sebuah pelayaan prospektif; (7) dapat menjadi komunitas alternatif yang jelas dan menarik bagi orang-orang yang mencari pelarian dari sebuah kegagalan sistemik; (8) dapat memilih untuk bekerja sama atau tidak bekerja sama dengan gereja-gereja lain dan pelayanan para gereja.

Sangat ditegaskan bahwa filsafat Kristen tidak sama dengan filsafat dunia (sekuler). Perbendaannya terletak pada sumber yang digunakan, yaitu kebenaran absolut. Untuk membedakannya digunakan pengertian worldview, yaitu filsafat yang sudah menjadi pandangan dan menjadi keyakinan seseorang. Ada dua jenis worldview, yaitu worldview sekuler dan worldview Kristen. Adapun worldview sekuler mencakup: Sementara, berkembang, bertentangan dengan sejarah, dapat direvisi, natural dan rasional. Sedangkan worldview Kristen yakni: kekal, tidak berubah, sejalan sejarah, biblikal, permanen, dan theistic. ${ }^{20}$

\section{Metafisika, Epistemologi, dan Aksiologi dalam Pendidikan Kristen}

Meracik filosofi pendidikan Kristen akan lebih komprehensi tentunya dengan memperhatikan tiga unsur pembentukan filsafat yaitu aspek metafisika, epistemology, dan aksiologi. Gambaran umum ketiga hal, diuraikan singkat Robert W. Pazmino $^{21}$,bahwa metafisika adalah studi tentang apa yang menyatakan tentang natur realitas dan apa yang dinyatakan dalam realitas tersebut. Dalam studi metafisika diajukan pertanyaan berikut, "apa yang nyata" dan metafisikan mencakup beberapa disiplin ilmu seperti teologi, antropologi, ontology, dan kosmologi. Teologi adalah studi tentang Allah yang mana berfungsi sebagai fondasi esensial bagi para pendidik teistik, sementara antropologi adalah studi tentang manusia, masyarakat, dan budaya. Ontologi adalah studi tentang keberadaan manusia dan kehidupan itu sendiri dan kosmologi adalah studi tentang dunia dan benda materi. Pembahasan kedua tentang epistemologi adalah studi tentang pengetahuan, membahas satu pertanyaan kunci, "apa yang benar". Aksiologi sebagai pembahasan ketiga adalah studi tentang nilai dan membahas satu pertanyaan kunci, yaitu "apa yang bernilai?. Aksiologi berhubungan dengan aspek penting yaitu etika dan estetika. Etika adalah studi tentang standar penilaian yang mempertimbangkan apa yang benar dan baik. Estetika adalah studi tentang keindahan yang mempertimbangkan apa yang indah..$^{22}$

\footnotetext{
${ }^{19}$ Rex E. Johnson "Fondasi Filosofis Pelayanan” dalam Foundation of Ministry An Introduction to Christian Education For A New Gereration, Edited \& Writenn Michael J. Anthony (Malang: Gandum Mas. 2012), 55-60

${ }^{20}$ Tung, Filsafat Pendidikan Kristen, 5-6

${ }^{21}$ Pazmino, Fondasi Pendidikan Kristen, 122

${ }^{22}$ George R. Knight, Philosophy and Education An Introduction in Christian Prespective (Berrien Springs, MI: Andrews University Press, 1980), 14-37
} 


\section{Metafisika dan pendidikan}

Metafisika merupakan pemahaman mengenai realitas (metaphysics=ta meta ta physika) yaitu apa itu realitas (what is real?) atau perkara di balik yang berwujud dan bergerak (the after physic). Realitas sesungguhnya tidaklah terbatas kepada atau tepatnya tidak sebatas kemampuan pengindraan, persepsi dan pemahaman manusia. DeJong menegaskan bahwa ide-ide penting dalam metafisika akan memengaruhi pendidik Kristen. Metafisika harus berkaitan dengan spekulasi keberadaan alam dan amkna dari realitas. Dengan potensi dan pemahaman yang kita miliki, kita dapat memberikan penjelasan mengenai aspek-aspek keyakinan metafisis.

Pertama, aspek kosmologi mencakup studi mengenai teori-teori tentang asal dari sesuatu, sifat dan perkembangan dari alam semesta sebagai sistem yang teratur. Dalam kaitannya dengan pendidikan Kristen kosmologi berbicara tentang keyakinan atas kejadian asal-usul, tujuam dan keteraturan (order) susunan dalam alam semesta (kosmos). Kosmologi mempelajari adakah "kekuatan atau "pribadi" di balik alam semesta? Jika ada siapakah dia?, dapatkah dia dijelaskan? (ada pemisah yang jelas atau tidak) atau monistik-hirarkis (menyatu dalam susunan atas-bawah). Tung menambahkan metafisika menyangkut keterkaitan hukum-hukum semesta dalam massa, ruang dan waktu. Bagaimana awal alam semesta terbentuk dan berkembang?,adakah tujuan yang hendak dicapai dari pembentukan alam semesta?.

Pertanyaan-pertanyaan di atas dapat dijawab dengan lebih dahulu mengemukakan bahwa dalam terang iman Kristen, realitas tertinggi adalah Tuhan, pencipta, dan pemelihara alam semesta. Alam semesta ada karena ada yang menciptakannya (mengadakannya), namanya Tuhan. Alam semesta tidak identik dengan Tuhan begitupun sebaliknya. Apa makna dalam pendidikan Kristen? Jika Tuhan adalah pencipta alam semesta, maka Ia juga adalah pencipta gagasan pendidikan, pengajaran, dan disiplin. Alkitab menuturkan bagaimana Tuhan mendidik manusia, baik individu maupun kelompok dari masa ke masa, agar mereka mengenal dan memuliakan Tuhan. Penulis Ibrani menyatakan bahwa Tuhan telah berbicara kepada orang-orang zaman dahulu, para nabi, dan rasul dengan berbagai cara. Pada puncaknya, Tuhan telah menyatakan diri kepada manusia di dalam atau melalui Yesus Kristus. Tung menjelaskan bahwa dalam iman Kristen berakhirnya dunia dengan kedatangan Yesus Kristus untuk kedua kalinya merupakan aspek yang harus dijawab dari aspek pendidikan Kristen dan teologi. Jadi Tuhan sendiri menjadi sumber inspirasi bagi manusia. Tuhan sendirilah yang ingin berbuat, serta melalui karya pendidikan yang manusia upayakan (Flp. 2:13).

Kedua, aspek teologi mencakup studi religious yang berkaitan dengan Tuhan. Teologi merupakan kajian yang membahas soal keberadaan, sifat dan perbuatan Tuhan bagi keutuhan ciptaan-nya. Pemahaman tentang Tuhan memiliki banyak varian seperti pemahaman yang berkembang tentang Tuhan seperti ateis, agnostik, deisme, animistic, panteistik, monoteistik, deistic, animistic, dinamistik, politeistik, dan teistik. Beberapa pemahaman sentral pada aspek teologis antara lain: apakah Tuhan itu ada?, bagiamana sifat-sifat Tuhan?, apakah Tuhan itu hanya satu atau lebih dari satu? Jika Tuhan itu baik dan berkuasa, bagaimana dengan kejahatan itu ada?, apa hubungannya dengan roh-roh, malaikat, dan setan?, jika ada apakah hubungannya roh-roh dengan Tuhan? Dalam kenyataanya manusia terpecah-pecah dalam berbagai kelompok dalam cara dan keyakinannya untuk menjawab pertanyaan tersebut. Kelompok ateis menyatakan Tuhan tidak ada. Kaum agnostik meragukan keberadaan Tuhan dan tidak dapat menyarakan apakah Tuhan itu ada atau tidak. Kaum deisme menyatakan Tuhan menciptakan hukum alam dan moral, tetapi Tuhan memisahkan keberadaan-Nya karena tidak tertarik pada manusia dan alam fisik. Tuhan itu mahajauh dari manusia, tak terhampiri oleh manusia. Harus ada perantara manusia dengan Tuhan. Mereka percaya hanya ada satu Tuhan yaitu pencipta. Manusia harus hidup menggunakan akal budi yang Tuhan berikan 
kepadanya. Kaum animisme menyatakan Tuhan identic dengan roh (anima) yang juga ada dimana-mana. Di mana roh menguasai dan mengendalikan dunia nyata.

Kaum politeisme menyatakan bahwa ada sejumlah Tuhan, Tuhan itu majemuk, dan banyak wujud dan bentuknya. Tuhan dapat beruba rupa atau bentuk apa saja yang dikehendakinya. Kaum Monoteisme menyatakan hanya ada satu Tuhan. Kaum panteistik mengatakan Tuhan berada dimana saja di dalam semesta ini, di tanah, air, udara dan api. Tuhan dan alam identeik, "Tuhan adalah segala-galanya, dan segala-galanya adalah Tuhan." Kaum monistik, manusia dengan Tuhan dapat menyatu, dan menurutnya panggilan manusia adalah menyatu dengan Tuhan asal mulanya sendiri. Manusia adalah pancaran dari Tuhan sendiri. Akhirnya pemahaman teistik bahwa Tuhan itu mahatinggi namun mahadekat karena Dia adalah Mahapribadi yang tak terbatas. Dia tetap ikut campur tangan dalam kehidupan manusia di dunia ini. Dia berkomunikasi dan berbicara dengan manusia.

Pandangan metafisika Kristen menyangkut dua lapisan dalam metafisikanya (theistic viewphysics) yaitu: Pertama, created universe, yaitu ciptaan yang terbatas, menempati, ruang tergantung, dan tidak tetap. Kedua, uncreated being of God, yaitu tidak terbatas, kekal, berada dengan sendirinya, self-sufficient, dan tidak diciptakan. Iman Kristen memiliki pemahaman tentang Tuhan secara teistik. Jika kita mempelajari teologi, kita harus terlibat dalam perbuatan "berteologi" (doing theology). Tidak hanya menyerap teologi sebagai hasil pemikiran orang lain atau para pakar, sekalipun kita orang biasa, sejauh kita mengalami relasi yang dinamis dengan Tuhan melalui Alkitab, Yesus Kristus, dan Roh Kudus, kita akan mampu berteologi. Pendidikan Kristen harus membimbingan orang dalam persekutuan dengan Tuhan, membimbing orang ke dalam komunikasi dan relasi dengan Tuhan sehingga dapat memahami kehendak-Nya dengan jelas untuk mendorong mengadakan refleksi, mengutarakan pemikiran secara sistematis tentang imannya dan pengalamannya sebagai hasil "pejumpaan (ancounter) dengan Tuhan dalam aktivitas berteologi. Pada akhirnya matefisika teologi Kristen mengarah pada Kisah Para Rasul 17:28 "sebab di dalam Dia kita hidup, kita bergerak, kita ada, seperti yang telah juga dikatakan oleh pujangga-pujanggamu" Sebab kita ini dari keturunan Allah juga".

Ketiga, aspek antropologi (Yunani: antropos dan logos) berkaitan dengan sifat,struktur manusia, termasuk pertanyaan sekitar asal dan tujuan hidup manusia?, apakah hubungan antara akal dan tubuh?, bagaimana interaksinya?, apakah akal budi lebih fundamental dibandingkan tubuh?, bagaimana status moral kemanusiaan?, apakah orang dilahirkan baik, jahat, atau netral scara moral?, sampai dimana setiap hidup individu dan bebas?. ${ }^{23}$ Pespektif iman Kristen, kita memiliki pemahaman bahwa ada manusia di dalam semesta bukanlah sebagai hasil peristiwa kebetulan. Manusia ada karena ada dan berkarya, karena adanya Tuhan yang menciptakan dan memelihara. Tuha sudah ada sebelum segala sesuatu ada, Ia menciptakan dari yang tiada (creation ex nihilo). Jadi manusia memiliki dimensi keutuhan dalam dirinya, sebagai mahkluk individu dan sosial. Manusia memiliki dimensi adikodrati sehingga manusia memiliki kemampuan mengenal Sang Penciptanya secara total dan dinamis. Sejak kejadiannya manusia diberikan nafas hidup (Kej.2:7), dimensi kekekalan (Pkh.3:11) suara hati manusia semacam "hakim" membedakan yang benar, baik dan buruk (Rm.2:14-15), dari dimensi adikodrati membuat manusia tidak bisa tidak beragama, tetapi juga harus hidup mandiri dan hidup bersosialisasi dan beradaptasi dengan lingkungannya. Dengan sarana agama, manusia mencari dan berjuang dekat dengan Tuhan, pribadi yang lebih besar

\footnotetext{
${ }^{23}$ Tung, Filsafat Pendidikan Kristen: Meletakkan Fondasi dan Filosofi Pendidikan Kristen di Tengah Tantangan Filsafat Dunia, 7-8
} 
dan berkuasa melindungi dan memelihara bahkan menghukumnya. Suara hati (hati nurani) manusia memberikan kesaksian rohani dan moral bahwa Tuhan itu ada dan memiliki sifat yang kasih dan adil. Inilah dasar dalam pembelajaran kristiani, kita harus sadar ada dimensi spiritual dalam proses pendidikan dimana Allah berintervensi melalui Roh Kudusnya melakukan pendidikan dan pembinaan bagi umat manusia (Fil. $4: 8,13)$.

Dengan demikian antropologi pada dasarnya berpusat pada natur manusia. Dari sudut padang kristiani, manusia dipandang sebagai ciptaan Allah yang diciptakan segambar dan serupa dengan Allah dan karenanya mempunyai tanggung jawab dan kewajiban sebagai pembawa gambar Allah. Namun manusia juga dipandang sebagai mahkluk yang sudah jatuh dan tercemar dosa yang membawa konsekuensi terhadap seluruh lapiran kehidupan manusia baik secara personal maupun secara korporat. ${ }^{24}$ Implikasi dalam dunia pendidikan bahwa manusia terus menerus didorong untuk bertindak secara bertanggung jawab dalam setiap relasi dan interaksinya lewat pendidikan, agar setiap peserta didik hidup sesuai tujuan Allah, memuliakan Tuhan dalam hidupnya, manusia juga harus dididik dengan natur kreatif Allah sehingga mereka menjadi pembaharu, membawa inovasi, dan produktif bagi bagi dirinya, keluarga, masyarakat, gereja dan bangsa negara. Semua disiplin pendidikan harus dipengaruhi dan diterangi oleh karya penebusan Kristus dan mengalami pemulihan hidup agar tujuan pendidikan itu sendiri dapat dicapai.

Tepatlah perkataan Pazmino, bahwa dengan mengenal natur manusia sebagai mahkluk ciptaan Allah, peserta didik bisa didorong untuk menjadi partisipan aktif dalam pendidikan mereka serta berinteraksi dengan dunia sebagai fokus hidup mereka. Karena itu studi tentang antropologi memaksa kita untuk mempertimbangkan hal yang tidak sekadar soal individu dan ruang kelas yang terisolasi. Manusia juga perlu dipandang dalam hubungannya dengan masyarakat dan budaya, hubungannya dengan sejarah yang bersifat antar pribadi dan korporat dan nasionalisme. Hal ini mendorong para pendidik Kristen untuk mempertimbangkan pertanyaan-pertanyaan yang bersifat antar pribadi, antar kelompok, antar masyarakat, dan antar budaya. Dalam kontek masyarakat ada berbagai kekuatan kelompok, gerakan, dan isntitusi yang bisa dinilai sebagai suatu tekanan atau justru sebagai suatu yang melegakan dalam rangka eksistensi manusia secara antropologi. ${ }^{25}$

Keempat,masalah ontology. Aspek ontology membahas sifat keberadaan (the nature of exsistence). Apakah yang dimaksudkan dengan keberadaan? Apakah yang ada? Sebenarnya terletak pada materi, atau juga non materi atau spritualkah?. Atau apakah hakikat dasar didapati unsur roh atau spiritual? Apakh hakikat itu tersusun dari satu unsur roh atau fisik, atau terdiri dari dua unsur?, apakah hakikat itu sudah tersusun dengan teratur atau mengikuti aturan dengan sendirinya? Pemahaman mengenai sifat keberadaan akan menentukan kembali jawaban terhadap apa yang paling bernilai dalam hidup. Manakah yang paling bernilai, yang material atau spiritual?, apakah kita hidup dalam tata nilai dualistic yang memisahkan perkara duniawi dengan perkara surgawi? Ontologi merupakan ilmu yang mempelajari sifat dari eksistensi (keberadaan atau maknanya bagi apa pun yang ada. Aspek ontology sering disebut dengan aspek isologi 26 karena fungsi ontologi adalah menentukkan hal yang kita maksudkan ketika kita menyatakan sesuatu itu dengan mendefinisikannya.

Secara ontology pendidikan harus berkaitan dengan hakikat utama yang menjadi sentral dari semua konsep pendidikan. Pendidikan harus didasarkan pada fakta bukan

\footnotetext{
${ }^{24}$ Pazmino, Fondasi Pendidikan Kristen, 123

${ }^{25}$ Pazmino, Fondasi Pendidikan Kristen, 124

${ }^{26}$ J. Donald Butler, Four Philosophies and Their Practice in Education and Religion (New York:Herper\&Row, 1968), 21
} 
hanya imajinasi apalagi ilusi. Teologi Kristen memandang bahwa keberadaan manusia tidak terbatas kepada yang sifatnya material belaka, tetapi juga terkait kepada yang spiritual. Manusia memiliki dimensi jasmani dan rohani dalam kesatuan namun manusia dibatasi ruang dan waktu dalam dimensi materialnya. Ia dapat hadir nanum tidak mahatahu, tidak mahahadir,dan tidak mahakuas. Manusia di dalam ruang dan waktu memerlukan pemenuhan segi spritualnya, sehingga beralih dari ruang dan waktu material ke ruang dan waktu kekekalan (1Kor.15:40-49). Pendidikan Kristen mengemban tugas menolong peserta didik agar dapat mengenal keberadaannya yang terbatas namun tidak pernah statis. Pendidikan Kristen terpanggil untuk melengkapi orang menjalani "pengembaraannya" di dalam dunia secara badani menuju kekekalan. Orang Kristen hadir sebagai orang buangan dan musafir di dunia, namun ia juga adalah seorang anggota kerajaan Allah yang menjalani hidup untuk mengalami pembaruan dan menyatakan hidup dari karya penebusan Kristus, manusia harus menjadi ciptaan baru dalam Kristus dan mengemban tugas mewartakan pendamaian Kristus bagi dunia (2 Kor. 5:17-21). ${ }^{27}$

Pendidik kristiani harus sadar pada dirinya dan menyadarkan peserta didiknya bahwa menjalani hidup di dunia ada batasnya namun punya tujuan kekal, maka sangat perlu roh takut akan Tuhan dan kerendahana hati bahwa semuanya dari kepada Tuhan dan memuliakan Tuhan (Pkh. 12:1-3, Mrk.12:29-30). Dalam pendidikan kristiani, hal utama dari metafisika secara ontology adalah kedaulatan Allah dalam setiap aspek kehidupan manusia. ${ }^{28}$

\section{Epistemology dan Pendidikan}

Istilah epistemologi berasal dari bahasa Yunani terdiri dari dua kata epistem $\eta$ episteme (pengetahuan) dan logoz - logos (kata, pikiran, percakapan, ilmu). Jadi epistemologi berarti kata, pikiran, percakapan tentang pengetahuan atau ilmu pengetahuan. ${ }^{29}$ Secara etimologi, epistemologi berarti teori pengetahuan. ${ }^{30}$ Menurut Uyoh Sadulloh mengutip pemikiran Runes (1963:94) bahwa epistemology is the branch of philosophy which investigates the origin, structure, method, and validity of knowledge" (Epistemologi merupakan cabang filsafat yang membahas atau mengkaji tentang asal, struktur, metode, serta keabsahan pengetahuan). ${ }^{31}$

Pemikiran yang sama dengan itu adalah seperti pemikiran secara tradional bahwa yang menjadi pokok persoalan dalam epistemologi adalah sumber, asal mula, dan sifat dasar pengetahuan, bidang, batas, dan jangkauan pengetahuan, serta validitas dan reliabilitas (reability) dari berbagai klaim terhadap pengetahuan. ${ }^{32}$ Adapun ciri-ciri dari Epistemologi adalah: (a) Bersifat sentral; posisi antara subjektif dan objektif. (b) Landasan bagi segenap tindakan mns dlm kehdpn sehari-hari. (c) Dasar bagi pengembangan pemikiran ilmiah. (d) Jembatan antara alam keharusan (das Sollen) yg bersifat kejiwaan dan alam empirik (das Sein) yg bersifat inderawi.

Selanjutnya untuk memperluas pemahaman kita tentang istilah epistemologi, Sriyulianti dalam bahan ajarnya menyebutkan beberapa istilah yang dapat dihubungkan dengan epistemologi, yaitu:33 (a) Kriteriologia: Menetapkan benar/tidaknya pikiran atau

\footnotetext{
${ }^{27}$ Pazmino, Fondasi Pendidikan Kristen, 125

${ }^{28}$ Tung, Filsafat Pendidikan Kristen: Meletakkan Fondasi dan Filosofi Pendidikan Kristen di Tengah Tantangan Filsafat Dunia, 8

${ }^{29}$ Jan Hendrik Rapar, Pengantar Filsafat (Yogyakarta: Penerbit Kanisius, 1996), 37

${ }^{30}$ Uyoh Sadulloh, Pengantar Filsafat Pendidikan (Bandung: ALFABETA, 2008), 29

${ }^{31}$ Sadulloh, Pengantar Filsafat Pendidikan, 29

${ }^{32}$ Rapar, Pengantar Filsafat, 37

${ }^{33}$ Rapar, Pengantar Filsafat, 37
} 
pengetahuan berdasarkan ukuran tentang kebenaran. (b) Kritikan Pengetahuan: Tinjauan secara mendalam utk menentukan benar/tidaknya pengetahuan manusia. (c) Gnoseologia: Gnosis (pengetahuan), logos (ilmu). Usaha untuk memperoleh hakikat pengetahuan yang bersifat keilahian. (d) Logika Material: Usaha menetapkan kebenaran suatu isi pemikiran.

Epistemologi memiliki cakupan yang sangat luas, hal itu dapat lihat pengertiannya, yaitu: ${ }^{34}$ (a) Epistemologi (teori pengetahuan) merupakan salah satu cabang filsafat yg mempelajari hakikat pengetahuan, sumber-sumbernya, syarat-syarat memperoleh pengetahuan, kebenaran dan kepastian pengetahuan serta hakikat kehendak dan kebebasan manusia dalam memperoleh pengetahuan. (b) Epistemologi adalah cabang filsafat yang khusus mempelajari pertanyaan-pertanyaan yang bersifat menyeluruh dan mendasar tentang pengetahuan. (c) Suatu upaya rasional untuk menimbang dan menentukan nilai kognitif pengalaman manusia dalam interaksinya dengan diri, dan lingkungan sekitarnya. (d) Suatu disiplin ilmu yang bersifat evaluatif (menilai), normatif (tentukan tolak ukur) dan kritis (mempertanyakan dan menguji). (e) Epistemologi atau filsafat pengetahuan adalah cabang filsafat yang mempelajari dan mencoba menentukan kodrat dan skope pengetahuan, pengandaian-pengandaian dan dasarnya serta pertanggungjawaban atas pernyataan mengenai pengetahuan yang dimiliki. (f) Epistemologi mengkaji tentang hakikat dan wilayah pengetahuan (episteme secara harafiah berarti "pengetahuan"). (g) Epistemologi membahas berbagai hal tentang pengetahuan seperti batas, sumber, serta kebenaran suatu pengetahuan.

Epistemologi berusaha membahas persoalan pengetahuan. Oleh sebab itu sering muncul serangkaian pertanyaan yang dapat diajukan untuk mendalami permasalahan yang dipersoalkan epistemologi, seperti: (a). Apakah pengetahuan itu?, (b). Apakah yang menjadi sumber dan dasar pengetahuan?, (c). Apakah pengetahuan itu berasal dari pengamatan, pengalaman, atau akal budi?, (d). Apakah pengetahuan itu adalah kebenaran yang pasti ataukah hanya merupakan dugaan?

Menurut Jan Henrik Rapar, pengetahuan dapat dibagi ke dalam tiga jenis yang dijelaskan sebagai berikut35: Pertama, Pengetahuan biasa (ordinary knowledge). Pengetahuan ini terdiri dari pengetahuan nir-ilmiah dan pra-ilmiah. Pengetahuan nirilmiah adalah hasil pencerapan dengan indera terhadap objek tertentu yang dijumpai dalam kehidupan sehari-hari, termasuk pengetahuan intuitif. Pengetahuan pra-ilmiah adalah hasil pencerapan inderawi dan pengetahuan yang merupakan hasil pemikiran rasional yang tersedia untuk diuji lebih lanjut kebenarannya dengan menggunakan metode ilmiah. Kedua, Pengetahuan ilmiah (Scientific Knowledge).Yang dimaksudkan dengan pengetahuan ilmiah adalah pengetahuan yang diperoleh lewat penggunaan metode-metode ilmiah yang lebih menjamin kebenaran yang dicapai. Pengetahuan yang demikian dikenal juga dengan sebutan science. Ketiga, Pengetahuan filsafati (Philosophical Knowledge). Pengetahuan filsafati diperoleh lewat pemikiran rasional yang didasarkan pada pemahaman, penafsiran, spekulasi, penilaian kritis, dan pemikiran-pemikrian logis, analitis, dan sistematis. Pengetahuan filsafati adalah pengetahuan yang berkaitan dengan hakikat, prinsip, dan asas dari seluruh realitas yang dipersoalkan selaku objek yang diketahui.

Apakah sebenarnya yang menjadi sumber pengetahuan?. Para filsuf memberi jawaban yang berbeda-beda terhadap pernyataan itu. Plato, Descartes, Spinoza, dan Leibniz mengatakan bahwa akal budi atau rasio adalah sumber utama bagi pengetahuan. Bahkan ada yang secara ekstrem menekankan bahwa aka budi adalah satu-satunya sumber bagi pengetahuan. Para filsuf yang mendewakan akal budi itu berpendapat

\footnotetext{
${ }^{34}$ Rapar, Pengantar Filsafat, 37

${ }^{35}$ Rapar, Pengantar Filsafat, 38-39
} 
bahwa setiap keyakinan atau pandangan yang bertentangan dengan akal budi tidak mungkin benar. Bagi mereka, pikiran memiliki fungsi yang amat penting dalam proses mengetahui. ${ }^{36}$ Paham yang menekankan bahwa sumber pengetahuan berasal dari rasio atau akal budi disebut paham atau aliran rasionalisme. Tokoh yang sangat terkenal mengembangkan aliran ini adalah Rene Descartes.

John Locke mengatakan bahwa seluruh ide manusia berasal secara langsung dari sensasi dan lewat refleksi terhadap ide-ide sensitif itu sendiri. Tidak ada suatu apa pun juga dalam akal budi manusia yang tidak berasal dari pengalaman inderawi. ${ }^{37}$ Paham yang menekankan bahwa sumber pengetahuan berasal dari pengalaman inderawi adalah paham atau aliran empirisisme. Tokohnya yang sangat terkenal adalah John Locke.

Imanuel Kant, seorang filsuf yang tidak sealiran dengan John Locke, menjembatani kedua aliran sumber pengetahuan yaitu rasio dan pengalaman inderawi mengatakan bahwa kendati seluruh ide dan konsep manusia bersifat apriori (suatu ide atau konsep ada pada dirinya sendiri) sehingga ada kebenaran apriori, ide dan konsep itu hanya dapat di aplikasikan apabila ada pengalaman. Tanpa pengalaman, seluruh ide dan konsep serta kebenaran apriori tidak akan pernah dapat diaplikasikan. Dengan kata lain, Kant hendak mengatakan bahwa akal budi manusia hanya dapat berfungsi sebagaimana mestinya apabila dihubungkan dengan pengalaman. ${ }^{38}$ Berdasarkan pemikiran dari beberapa filsuf di atas, maka dapat disimpulkan bahwa sumber-sumber pengetahuan berasal dari rasio atau akal budi dan pengalaman inderawi manusia.

Selain itu dilihat dari sumber pengetahuan, Uyoh Sadulloh dalam bukunya Filsafat Pendidikan mengatakan bahwa manusia berusaha mencari pengetahuan dan kebenaran, yang dapat diperolehnya dengan melalui beberapa sumber yaitu pengetahuan wahyu (reveled knowledg), pengetahuan intuitif (intuitive knowledge), pengetahuan rasional (rational knowledge), pengetahuan empiris (empirical knowledge), dan pengetahuan otoritas (authoritative knowledge). ${ }^{39}$ Pertama. Pengetahuan Wahyu (Reveled Knowledge). Dalam perjalanan hidup manusia, sebagaian manusia memperoleh pengetahuan dan kebenaran atas dasar wahyu yang diberikan Tuhan kepada manusia. Tuhan telah memberi pengetahuan dan kebenaran kepada munusia pilihannya, yang dapat dijadikan petunjuk bagi manusia dalam kehidupannya. Wahyu merupakan firman Tuhan. Kebenarannya adalah mutlak dan abadi. Pengetahuan wahyu bersifat eksternal, artinya pengetahuan tersebut berasal dari luar manusia. Kedua, Pengetahuan intuitif (Intuitive Knowledge). Dalam pengertian umum, intuisi merupakan metode untuk memperoleh pengetahuan tidak berdasarkan penalaran rasio, pengalaman, dan pengamatan indera. Pengetahuan intuitif diperoleh manusia dari dalam dirinya sendiri, pada saat ia menghayati sesuatu. Pengetahuan intuitif muncul secara tiba-tiba dalam kesadaran manusia. Mengenai proses kerjanya, manusia itu sendiri kadangh-kadang tidak menyadarinya.

Ketiga, Pengetahuan Rasional (Rational Knowledge). Pengetahuan rasional merupakan pengetahuan yang diperoleh dengan latihan rasio/akal semata, tidak disertai dengan observasi terhadap peristiwa-peristiwa faktual. Prinsip logika formal dan matematika murni merupakan paradigma pengetahuan rasional, dimana kebenaranya dapat ditunjukan dengan pemikiran abstrak. prinsip pengetahuan rasional dapat di terapkan pada pengalaman indera, tetapi tidak kesimpulan dari pengalaman

\footnotetext{
${ }^{36}$ Rapar, Pengantar Filsafat, 39

${ }^{37}$ Rapar, Pengantar Filsafat, 37

${ }^{38}$ Rapar, Pengantar Filsafat, 40

${ }^{39}$ Sadulloh, Pengantar Filsafat Pendidikan,30-33
} 
indera. Rasionalisme adalah aliran dalam filsafat yang mengutamakan rasio untuk memperoleh pengetahuan dan kebenaran. Rasionalisme berpandangan bahwa akal merupan faktor fundamental dalam pengetahuan. Akal manusia mempunyai kemampuan untuk mengetahui kebenaran alam semesta, yang tidak mungkin dapat diketahui melalui observasi. Menurut rasionalisme, pengalaman tidak mungkin dapat menguji kebenaran hukum "sebab-akibat" karena peristiwa yang tidak terhingga dalam kejadian alam ini tidak mungkin dapat di observasi.

Keempat, Pengetahuan Empiris (Empirical Knowledge. Pengetahuan emperis diperoleh atas bukti penginderaan, dengan penglihatan, pendengaran, dan sentuhan indera-indera lainya, sehinga kita mempunyai konsep duynia di sekitar kita. Paradigma pengetahuan emperis adalah sains, dimana hipotesis-hipotesis sains diuji dengan observasi atau dengan eksperimen. Aliran yang menjadikan emperis (pengalaman) sebagai sumber pengetahuan di sebut empirisme. Emperisme merupakan aliran dalam filsafat yang membicarakan pengetahuan.Emperisme beranggapan bahwa pengetahuan dapatb diperoleh melalui pengalaman, dengan jalan observasi, atau penginderaan. Pengalaman merupakan faktor fundamental dalam penetahuan, sehingga merupakan sumber dari pengetahuan manusia. Apa yan kita ketahui berasal dari segala apa yang kita dapatkan melalui alat indera. Pengalaman merupakan proses interaksi antara manusia dan lingkunganya. Pengalaman tidak hanya sekedar dunia fakta, melainkan termasuk pula dunia penelitian, dimana dalam pengertian ini termasuk dunia sains.

Kelima, Pengetahuan Otoritas (Authoritadiive Knowledge). Kita menerima suatu pengetahuan itu benar bukan karena telah menceknya diluar kita, melainkan telah dijamin oleh otoritas (suatu sumber yang beribawa, memiliki wewenang, berhak) di lapangan. Kita menerima pendapat orang lain, karena ia adalah seorang pakar dalam bidangnya. Misalnya kita menerimah petuah agama dari seorang kiai, karena beliau merupakan orang yang sangat ahli dan menguasai sumber ajaran agama islam,tanpa kita mencek dari sumber aslinya (Quran dan Sunnah). Kita sering mengutamakan pandangan kita dengan mengutip dari ensiklopedia atau hasil karya tulis para pakar yang terkenal. Pada saman kerajaan, sabda raja merupakan manusia yang paling berkuasa.

Menurut Louis 0. Kattsoff, kebenaran menunjukkan bahwa makna suatu pernyataan, artinya proposisinya - sungguh-sungguh merupakan halnya. Hal ini sejalan dengan pemikiran dari penganut idealisme, seperti F.H. Bradley, mengatakan bahwa kebenaran ialah kenyataan. Karena kebenaran ialah makna yang merupakan halnya, dan karena kenyataan ialah juga merupakan halnya, maka keduanya dipandang sama sepenuhnya. Misalnya, karena makna pernyataan "di luar hawanya dingin", artinya proposisi di luar hawanya dingin, sekarang sungguh-sungguh merupakan halnya pada waktu menulis catatan ini, maka keadaan-dingin-di luar merupakan bagian dari keadaan kenyataan yang ada pada waktu sekarang serta pada tempat ini, proposisi tersebut dikatakan benar. ${ }^{40}$

Ukuran kebenaran sesungguhnya tergantung pada apakah sebenarnya yang diberikan kepada kita oleh metode-metode untuk memperoleh pengetahuan. Jika apa yang kita ketahui ialah ide-ide kita, maka pengetahuan hanya dapat terdiri dari ide-ide yang dihubungkan secara tepat, kebenaran merupakan keadaan-saling-berhubungan (coherence) di antara ide-ide tersebut atau keadaan saling berhubungan di antara proposisi-proposisi. Jika sebaliknya, kita dengan suatu cara tertentu mengetahui kenyataan, maka pengetahuan atau ide-ide yang benar terdiri dari - seperti yang dikatakan Spinoza - kejumbuhan antara ide dengan ideantumnya, atau selanjutnya kesesuaian (correspondence) antara ide-ide dengan apa yang diwakili. ${ }^{41}$

\footnotetext{
${ }^{40}$ Lois O. Kattsoff, Pengantar Filsafat (Yogyakarta: Tiara Wacana Yogya, 2004), 173

${ }^{41}$ Kattsoff, Pengantar Filsafat, 175
} 
Beberapa teori yang dapat dijadikan acuan untuk menentukan apakah ukuran pengetahuan itu benar atau salah, yaitu: 1). Teori korepondensi; 2). Teori koherensi, dan 3). Teori pragmatisme. Pertama, Teori Korespodensi (Correspondence Theory). Paham yang mengatakan bahwa suatu pernyataan itu benar jika makna yang dikandungnya sunguh-sungguh merupakan halnya, dinamakan "paham korespondensi". Keadaan atau keadaan benar berupa kesesuaian (correspondence) antara makna yang dimaksudkan oleh suatu pernyataan dengan apa yang sungguh-sungguh merupakan halnya, atau apa yang merupakan fakta-faktanya. ${ }^{42}$ Apakah yang dimaksudkan dengan istilah kesesuaian?. Menurut K. Rogers seorang penganut realisme kritis dari Amerika, mengatakan bahwa kesesuaian itu berlaku di antara esensi-esensinya. Setiap esensi mempunyai dua segi, yang satu terdapat di dalam objeknya dan yang lain sebagai makna. Segi esensi yang berupa makna bersifat kejiwaan. Dalam suatu pencerapan, kita secara diam-diam mengenal esensi yang termasuk objeknya, maupun apa yang dimaksudkan oleh esensi tersebut. Dengan kata lain, apa yang dikatakan oleh Rogers ialah, bahwa keadaan-keadaan terletak dalam kesesuaian antara esensi atau makna yang kita berikan dengan esensi atau makna yang terdapat di dalam objeknya. Maka yang berkesesuaian itu bukanlah makna dengan objeknya, melainkan esensi sebagai makna dengan esensi yang terdapat di dalam objek. ${ }^{43}$

Menurut teori korespodensi, kebenaran merupakan persesuaian antara fakta dan situasi nyata. Kebenaran merupakan persesuaian antara pernyataan dalam pemikiran dengan situasi lingkungannya. Teori ini paling luas diakui oleh kaum realis. Sebagai contoh, saya berpendapat bahwa pulau Jawa merupakan pulau terdapat penduduk di Indonesia . pendapat saya itu benar bukan karena bersesuai dengan pendapat orang lain sebelumnya, atau karena di terima oleh banyak orang, melainkan karena persesuaian dengan kenyataan yang sebenarnya. Ini merupakan ciri dari ilmuan yang selalu mencek atau mengontrol pikiran-pikirannya dengan data-data atau penemuan-penemuan. ${ }^{44}$

Kedua, Teori Koherensi (Coherence Theory). Penganut kohenrensi tentang kebenaran biasanya dianut oleh para pendukung idealisme, seperti filsuf Britania F.H. Bradley (1846-1924). Secara singkat paham tersebut mengatakan bahwa suatu proposisi cenderung benar jika proposisi tersebut dalam keadaan saling berhubungan dengan proposisi lain yang benar, atau jika makna yang dikandungnya dalam keadaan saling berhubungan dengan pengalaman kita. Contoh, bagaimana cara kita mengatakan bila seseorang bohong dalam banyak hal? Jawabnya dengan jalan menunjukkan bahwa apa yang dikatakan tidak cocok dengan hal-hal lain yang telah dikatakannya atau dikerjakannya. ${ }^{45}$

Teori koherensi menganut hukum-hukum keadaan saling berhubungan. Bradley mengatakan bahwa yang dimaksudkan para penganut idealis tentang hukum-hukum keadaan saling berhubungan, dapat diketahui dari dua ciri pokok, yaitu: Pertama, adanya keharusan bahwa semua fakta terangkum. Ide-ide tidak mungkin saling berhubungan jika ide-ide itu hanya merupakan bagian-bagian dari kebenaran seluruhnya. Kedua, ide-ide tersebut harus teratur secara selaras dan tidak mengandung kontradiksi. Kenyataan (dan karenanya, kebenaran) oleh para penganut idealisme digambarkan sebagai sistem kebenaran yang teratur, yang logis, yang didalamnya tidak terdapat kontradiksi. ${ }^{46}$

\footnotetext{
${ }^{42}$ Kattsoff, Pengantar Filsafat, 179

${ }^{43}$ Kattsoff, Pengantar Filsafat, 180

${ }^{44}$ Sadullo, Pengantar Filsafat Pendidikan, 38

${ }^{45}$ Kattsoff, Pengantar Filsafat, 176

${ }^{46}$ Kattsoff, Pengantar Filsafat, 177
} 
Menurut teori koherensi, kebenaran bukan bersesuai antara pikiran dengan kenyataan , melainkan kesesuaian secara harmonis antar pendapat/pikiran kita dengan pengetahuan kita yang telah dimiliki. Teori ini pada umumnya diakui oleh golongan idealis. Pengertian persesuaian dalam teori ini terdapat konsistensi (ketetapan, sehingga teori ini berarti terdapat konsistensi (ketetapan, sehingga teori ini disebut juga teori konsistensi) yang merupakan ciri logis hubungan antara pikiran-pikiran (ide-ide) yang telah kita miliki satu dengan yang lain. Kalau kita menerima pengetahuan baru, karena pengetahuan tersebut sesuai dengan pengetahuan yang kita miliki,atau apa bilah kita melepaskan pendapat lama, karena pendapat baru tersebut lebih bertautan secara harmonis dengan keseluruhan pangalaman pengetahuan kita.

Kedua, Teory Pragmatisme (Pragmatism Theory).Menurut teori pragmatisme, kebenaran tidak bersesuai dengan kenyataan, sebab kita hanya bisa mengetahui dari pengalaman kita saja. Di lain pihak, menurut pragmatisme, teori koherensi adalah normal dan rasional. Pragmatisme berpendirian bahwa mereka tidak mengetahui apapun (agnostik) tentang wujud, esensi, intelektualitas, rasionalitas. Oleh klarena itu, pragmatisme merupakan penganut emperisme yang fanatik untuk memberikan interperensi terhadap pengalaman. Menurut pragmatisme, tidak ada kebenaran yang mutlak dan abadi. Kebenaran itu dibuat dalam proses penyusaian manusia.

Schiller, pengikut pragmatisme di Inggris, mengemukakan bahwa kebenaran merupakan suatu bentuk nilai, artinya apabila kita menyatakan benar terhadap sesuatu, berarti kita memberikan penilain terhadapnya. Istilah benar adalah suatu pernyataan yang berguna, sedangkan istilah salah merupakan pernyataan yang tidak berguna. Seseorang menyatakan pendapatnya bahwa benar, karena telah memenuhi kepentinganya. Dapat terjadi seseorang menyatakan benar, tetapi suatu saat ia menyatakan pendapatnya itu salah, karena pendapatnya itu sudah tidak berguna, tetapi hanya dapat memenuhi kepentinganya. Tetapi, dalam hal ini tidak berarti bahwa benar dan salah merupakan hal yang bersifat individual. Kebenaran merupakan hasil hubungan sosial. Kebenaran individual dikontrol atau dikoreksi di bawah pengaruh sosial, sampai akhirnya kebenaran itu diterima secarah umum.

Para penganut ajaran-ajaran pragmatisme berbeda-beda coraknya, sesuai dengan konsekuensi-konsekuensi yang mereka tekankan. Namun, semua penganut pragmatisme meletakkan ukuran kebenaran dalam salah satu macam konsekuensi. Sebagai contoh, William James, mengatakan bahwa proposisi "Tuhan ada" adalah benar bagi seseorang yang hidupnya mengalami perubahan karena percaya adanya Tuhan. Ini berarti bahwa proposisi-proposisi yang membantu kita mengadakan penyesuaianpenyesuaian yang memuaskan terhadap pengalaman-pengalaman kita, adalah benar. Dalam batas-batas tersebut, kebenaran merupakan gagasan yang berguna atau dapat dilaksanakan di dalam suatu situasi. Dan orang mempunyai kehendak serta hak untuk percaya akan hal-hal yang membantu menetapkan hubungan yang memuaskan dengan sisa pengalaman mereka. Kiranya jelas, bahwa kesulitan besar tentang definisi mengenai kebenaran sebagai sesuatu uang berguna dalam menetapkan penyesuaian-penyesuaian yang memuaskan, tergantung pada apa yang dimaksudkan dengan "dapat dilaksanakan" atau "berguna", dan tergantung pada apakah yang merupakan hubungan-hubungan yang memuaskan dengan sisa pengalaman kita. ${ }^{47}$

Karena itu untuk mencari kebenaran, kaum pragmatis berpaling pada metode sains (ilmiah), sebab, metode ini dianggapnya berfungsi dan berguna dalam menafsirkan gejala-gejala alam. Kriteria pragmatisme banyak digunakan oleh ilmuan untuk menentukan kebenaran ilmiah dalam jangka waktu tertentu, karen seperti yng telah dikemukakan di atas, bagi pragmatisme tidak ada kebenaran mutlak dan abadi.

\footnotetext{
${ }^{47}$ Kattsoff, Pengantar Filsafat, 182-183
} 
Keempat, Teori Kesahihan Semantik (Semantik theory of Truth).Perihal teori Kesahihan Semantik (Semantik theory of Truth) dan Teori Kesahihan Logikal yang berlebih-lebihan (Logical Superfluity Theory of Truth) dikutip dari tulisan Jan Hendrik Rapar. ${ }^{48}$ Yang dimaksudkan teori Kesahihan Semantik (Semantik theory of Truth) adalah teori yang menekankan arti dan makna suatu proposisi. Bagi teori kesahihan semantik, proposisi harus menunjukkan arti dan makna sesungguhnya yang mengacu kepada referen atau realitas dan bisa juga arti definitif dengan menunjuk ciri khas yang ada. Kelima. Teori Kesahihan Logikal yang berlebih-lebihan (Logical Superfluity Theory of Truth). Teori Kesahihan Logikal yang berlebih-lebihan (Logical Superfluity Theory of Truth) adalah sebuah teori yang hendak menunjukkan bahwa proposisi logis yang memiliki term berbeda tetapi berisi informasi sama tak perlu dibuktikan lagi, atau ia telah menjadi suatu benda logik yang berlebih-lebihan. Contoh: siklus adalah lingkaran atau lingkaran adalah bulatan dan sebagainya. Dengan demikian, proposisi lingkaran atau bulat tidak perlu dibuktikan lagi kebenarannya. ${ }^{49}$

Dalam perspektif iman Kristen, epistemology Kristen adalah firman Tuhan dalam mendapatkan pengetahuan. Prinsip dan praksis pendidikan harus berdasarkan pandangan Akitab. Dalam Amsal 3:5-6 "percayalah kepada Tuhan dengan segenap hatimu, dan jangalah bersandar kepada pengertianmu sendiri. Akuilah Dia dalam segala lakumu, maka Ia akan meluruskan jalanmu". Demikian pula dalam Mazmur 119:15 "firman-Mu itu pelita bagi kakiku dan terang bagi jalanku". Landasan ini akan memberi pencerahan dan tugas kepada stakeholder pendidikan Kristen bahwa kebenaran firman Tuhan harus menjiwai seluruh proses pendidikan kristiani. Kebenaran firman Tuhan harus dipahami sebagai kesatuan dalam tritunggal Allah berkaitan dengan prinsip dan praksis pendidikan, yakni: Firman yang berkenaan dengan penciptaan, firman yang hidup dan berikarnasi dalam Yesus Kristus, dan firman yang dituliskan untuk manusia yaitu Alkitab (2 Tim.3:16). ${ }^{50}$

Perspektif yang alkitabiah harus menjadi bagian terpenting mendalami epistemology kristiani. George Knight menjelaskan bahwa: (a) Perspektif Alkitab menyatakan seluruh kebenaran adalah kebenaran Allah, itu berarti mengeliminir pemahaman bahwa ada perbedaan kebenaran sekuler dengan kebenaran rohani, (b) Kebenaran dari penyataan kristiani adalah benad adanya sesuai dengan apa yang ada di alam semesta, sehingga orang Kristen harus berusaha mendapatkannya tanpa kuatir adanya kontradiksi. (c) Kekuatan jahat berusaha merendahkan Alkitab, membelokkan pemikiran manusia, dan mengarahkan manusai untim bergantung pada ketidakmampuan diri sendiri yang sudah jatuh dalam dosaa dalam upaya mencari kebenaran tidak akan berhasil. (d) Alkitab tidak hanya berisi kebenaran abstrak, tetapi juga kebenaran berkaitan dengan kehidupan. Karena itu pengetahuan Alkitab dalam diterapkan dalam kehidupan sehari-hari. (e) berbagai sumber pengetahuan tersedia bagi orang Kristen (wahyu umum dan wahyu khusus) bersifat saling melengkapi dan saling meneguhkan seturut pola Alkitab. (f) Adanya keutuhan kebenaran, penerimaan epistemology kristiani tidak bisa dipisahkan dari metafisika kristiani. ${ }^{51}$

\section{Aksiologi dan Pendidikan}

\footnotetext{
${ }^{48}$ Rapar, Pengantar Filsafat, 43

${ }^{49}$ Rapar, Pengantar Filsafat, 43

${ }^{50}$ Tung, Filsafat Pendidikan Kristen: Meletakkan Fondasi dan Filosofi Pendidikan Kristen di Tengah Tantangan Filsafat Dunia, 11

${ }^{51}$ Knight, Philosophy and Education An Introduction in Christian Prespective (Berrien Springs, MI: Andrews University Press, 1980), 61-62
} 
Aksiologi merupakan cabang dari filsafat yang berbicara tentang nilai (what is of value). Nilai dapat diartikan sebagai sesuatu yang berharga, berkualitas, bermakna, dan bertujuan dalam kehidupan sehari-hari manusia, baik secara individu dan kelompok. Umumnya orang menimbang nilai dari kadar baik dan buruk. Disamping itu nilai mengarahkan tindakan, mendasari perbuatan, dan membuat preferensi nilai (sistem nilai atau tata nilai), dalam hidup manusia memiliki sistem nilai dalam angan (conceived values) dan nilai dalam praktik sebagai suatu keharusan (operatif values). Pendidikan kristiani menawarkan nilai hidup baru yang bersumber pada Alkitab dan penebusan Yesus Kristus. Yesus Kristus mengajarkan dan memberikan nilai hidup bagi para pengikut-Nya dan mendorong untuk menghidupi dan mewujudkan nilai-nilai itu ke dalam hidup nyata yang menembus ragam manusia, budaya, masyarakat dan bangsa.

Aspek aksiologi menyangkut etika dan estetika. Etika adalah studi tentang prinsip moral dan praktiknya. Etika berurusan dengan realitas dosa dan panggilan kristiani untuk melayani dan berkorban bagi dunia. Estetika adalah studi tentang keindahan dan dimensi kreatif dalam hidup. ${ }^{52}$ Etika merupakan studi tentan nilai-nilai moral dan perilaku. Etika menjawab pertanyaan: "apakah itu kebaikan, apa yang seharusnya dilakukan orang pada saat situasi seperti ini?". Estetika adalah studi dari nilai-nilai umum, prinsip-prinsip yang mengatur penciptaan dan penghargaan terhadap keindahan dan seni. Estetika menjawab pertanyaan: "apakah itu keindahan, apa yang indah dari seni tersebut?. Etika dan estetika pendidikan Kristen bertujuan memuliakan Tuhan dan mengasihi sesama. Etika bersumber dari pewahyuan khusus, estetika bersumber pada doktrin keindahan realitas ciptaan Allah. Studi tentang etika merupakan studi dari kehendak bebas manusia dengan kesadaran untuk bertindak benar atau salah. ${ }^{53}$

Pertama, masalah etika adalah masalah yang baik dan buruk berkaitan dengan masalah ukuran, norma terhadap apa yang kita sebut baik dan apa yang kita sebut buruk. Pendidikan Kristen berurusan dengan pembentukan dan pengembanghan nilai hidup. Nilai yang diajarkan itu adalah yang mampu membentuk dasar moral dan etis kehidupan orang percaya. Nilai hidup itu bersumber dari Tuhan bukan dari manusia dan dunia. Nilai-nilai dari yang diajarkan Yesus dalam khotbah di bukit Matius 5-7 tentang kebenaran dan hidup secara pribadi, dasar ibadah, dan dasar dari agama. Nilai hidup harus konsisten dan selarah dengan kehidupan itu sendiri, Yesus secara tegas mengatakan diri-Nya tidak berubah, baik kemarin,hari ini, dan selama-lamanya (Ibr. 13:8). Panggilan pendidikan Kristen yang sangat mendesak adalah membimbing orang agar mengenal Tuhan yang mahakudus, mahaadil, mahabenar. Relasih kekudusan hidup harus menjadi benih yang hidup bagi kehidupan etikan orang percaya (Mzm. 119:19).

Kedua, masalah estetika. Aksiologi tidak terlepas dari masalah estetika, yakni bidang yang membahas keindahan, kerapian, kreatifitas dan inovasi setiap individu. Estetika juga sangat berhubungan dengan masalah emosi, kognisi, serta efeksi. Pendidikan Kristen mengarahkan dalam proses belajar mengajar dimana memperhitungkan segi-segi keindahan dan kerapian serta penampilan diri sehingga nampak kehormatan dan peradaban hidup dari manusia itu sendiri. Imajinasi dan kreatifitas serta inovasi adalah bagian dari hakikat manusia sebagai pembawa rupa dan gambar Tuhan (imago dei) (Kej.1:26-27). Manusia sebagai ciptaan Tuhan memiliki daya cipta dan kreasi, daya imajinasi dan khayal ilmiah, yang diperlukan bagi pengembangan ilmu pengetahuan dan hasil-hasilnya yang berguna bagi kesejahteraan manusia.

Dalam persepktif Kristen, etika adalah bentukan normatif dari suatu panduan yang tidak berubah, tidak subjektif, dan tidak situasional. Etika Kristen tidak berbasis pada

\footnotetext{
${ }^{52}$ Pazmino, Fondasi Pendidikan Kristen, 134

${ }^{53}$ Tung, Filsafat Pendidikan Kristen: Meletakkan Fondasi dan Filosofi Pendidikan Kristen di Tengah Tantangan Filsafat Dunia, 13
} 
nilai yang berdasarkan prinsip-prinsip yang ditentukan komunitas atau rentang waktu tertentu, tetapi berdasarkan kebenaran firman Tuhan. ${ }^{54}$ Menghidupkan etika kristiani haruslah menghindari kesombongan dan pemberontakan manusia, dan semuanya memikirkan dan menghidupi dengan nyata apa yang dikatakan Paulus dalam Filipi 4:8 "jadi akhirnya, saudara-saudara, semua yang benar, semua yang mulia, semua yang adil, semua yang suci, semua yang manis, semua yang sedap didengar, semua yang disebut kebajikan dan patut di dipuji pikirkanlah semuanya itu."

Bagi orang Kristen, estetika didasarkan pada fakta bahwa Allah menciptakan dunia itu indah, dan ini mengimplikasikan suatu tanggung jawab pribadi baik untuk menghargai maupun untuk menciptakan keindahan. Hubungan aksiologi dan pendidikan bisa dieksplorasi dengan mempertimbangkan berbagai sistem nilai yang berbeda yang memengaruhi tujuan umum dan tujuan khusus pendidikan. Paulo Freire menekankan betapa pentingnya artikulasi yang jelas dari nilai-nilai tersebut dalam pendidikan dan perlunya refleksi kritis terhadap nilai-nilai dan terhadap problematisasinya.

Aspek-aspek aksiologi kristiani yang termaktup dalam segi etika dan estetika haruslah bersumber pada panggilan pelayanan pendidikan yang mencintai dan melayani Tuhan, mencintai dan melayani sesame manusia, mencintai dan menghidupi firman Tuhan dan hukum-hukum Tuhan dan alam semesta. Tujuan pembelajaran etika dan estetika hendaknya bermuara pada pengembangan karakter, pengembangan keterampilan pelayanan, dan pengembanga tanggung jawab manusia bagi sesamanya dan bagi alam semesta terutama kepada Tuhan. ${ }^{55}$ Tujuan akhir dari etika dan estetika kristiani adalah pembentukan karakter Kristen dan mengembangkan seni dan keindahan sebagai pemberian dan anugerah Tuhan yang diwujudkan dalam kehidupan sehari-hari bagi hormat dan kemuliaan Tuhan, bagi kesejahteraan manusia dengan segala kelimpahan sukacitanya.

\section{Integrasi Iman dan Ilmu dalam Praksis PAK}

Berbicara ilmu tidak terlepas dari aspek rasio yang melatarbelakanginya. Banyak manusia ingin membuktikan kebenaran melalui rasionya. Rasio merupakan bagian yang ada dalam diri manusia sebagai mahkluk ciptaan Tuhan. Dari rasiolah menjadi dewa dalam konteks ilmu pengetahuan. Para abad 17 dan 18 seperti Hegel, Charles Darwin, Karl Mark, Ludwig Feuerbach, Immanuel Kant, mendalilkan bahwa rasio adalah segalagalanya lalu seolah-olah tidak lagi mengakui iman dan ajaran Kristen dan bahkan menolak keberadaan Allah. Darwin dengan teori revolusionernya tentang evolusi seolah-olah menegaskan manusia dan rasionya adalah segala-galanya. Tetapi sekarang dimanakah mereka semuanya?, mereka telah tenggelam dalam kematian yang mengerikan jika tidak bertobat. Mereka lpau bahwa semua kebenaran tidak dapat diuji kebenarannya hanya dengan ilmu pengetahuan dan rasio saja tetapi juga harus diterima dengan iman sebagaimana Alkitab menegaskan dalam Roma 10:17, "iman timbul dari pedengaran, dan pendengaran oleh firman Yesus Kristus, berarti ada dua pihak yang saling terlibat, yaitu manusia dengan iman dan rasionya dan Allah dengan kasih, keadilan dan kedaulatan-Nya.

Jika kita berbicara tentang Pendidikan Agama Kristen, kita juga tidak bisa melepaskan dari peranan iman dan rasio. PAK merupakan proyeksi iman yang disosialisasikan melalui berbagai aspek kehidupan sedangkan ilmu sebagai cara untuk

\footnotetext{
${ }^{54}$ James Braley, Jack Layman, and Ray White, Foundation of Chritian School Education (Colorado Springs: Purposeful Design, 2003), 13

${ }^{55}$ Tung, Filsafat Pendidikan Kristen: Meletakkan Fondasi dan Filosofi Pendidikan Kristen di Tengah Tantangan Filsafat Dunia, 14
} 
menganalisis, mengkritisi, dan mengevaluasi. Para pemikir Kristiani telah bergulat dalam sejarah dimasanya untuk mencari hakikat yang benar dari pendidikan Kristen. Benar ada ketegangan khususnya dalam dinamika PAK, seperti penyataan dari Thomas Groome bahwa benar ada ketegangan khususnya terjadi disekitar perbedaan persektif prinsip, praksis, dan metode mengajar, seperti ketegangan dari pemikiran Comenius (1592) yang mengusulkan metode mengajar induktif di bawah bimbingan alam, para pendidik lain seperti Pattalozzi dan Froebel yang mengusulkan pendidikan yang berorientasi dan berpusat pada peserta didik. Whitehead, mengusulkan pendidikan harus berbasis keagamaan.

Hal ini terjadi karena perbedaan worldwiew. Soegiharjo mengatakan bahawa "cara pandang manusia atau pandangan tentang dunia yang benar inilah yang seharusnya dimiliki dan dipahami oleh setiap orang Kristen yang akan membantunya untuk menilai segala sesuatu secara benar dan sesuai dengan iman yang diterimanya. Manusia pada hakekatnya adalah mahkluk rasional yang dapat memahami ilmu pengetahuan secara teori dan praksis. Dalam iman Kristen dengan ilmu pengetahuan, rasio manusia dapat meresapi, menemukan, dan menciptakan suatu kebenaran empiris yang dapat menguji dan membuktikan segala sesuatu yang dapat berguna bagi kemanusiaan. Namun semua kebenaran ilmiah, kebenaran ilmu pengetahuan harus tetap dievaluasi oleh dan harus tunduk pada firman Tuhan. Ibrani 11:3 bahwa karena "iman kita mengerti bahwa alam semesta ini telah dijadikan oleh firman Allah, sehingga apa yang kita lihat telah terjadi dari apa yang tidak dapat kita lihat."

Stephen Tong, meyakini bahwa harus ada keseimbangan kita tidak boleh meniadakan rasio tetapi juga tidak boleh memperilah rasio. Orang Kristen harus menggunakan rasio sebaik mungkin tetapi tidak boleh jatuh menjadi seorang rasionalis. ${ }^{56}$ Ibrani 11:1 adalah jawabannya bahwa iman adalah dasar dari segala sesuatu. Iman yang dipahami orang Kristen adalah iman yang memberi ruang kepada rasio untuk mengeksplorasi semua ilmu pengetahuan dan alam semesta alam untuk menemukan kebesaran dan kedasyatan kuasa Allah.

Namun benar yang dikatakan para pemikir Kristen seperti Thomas Groome, Benhoeffer "tidak ada anugerah yang murah", dalam praksis pendidikan bahwa pendidikan itu tidak gampang, tidak mudah, dan merupakan suatu usaha sadar dari bentuk kerja keras dan bertanggung jawab. Pertama, Thomas Groome dengan praksis pemikiran Aristoteles, yang mengatakan bahwa manusia boleh bebas dalam berpikir dengan cerdas dengan cara theoria, praxis, dan poiesis. Ketiga gaya ini sebagai gaya hidup spekulatif, praktis, dan produktif. Cara pandang theoria adalah pencarian kebenaran dengan proses kontemplatif atau reflektif atau tidak terlibat. Cara mengetahui praksis dengan keterlibatan reflektif dalam situasi sosial. Sedang poiesis sebagai cara mengetahui yang terwujud dalam dan muncul dalam cara "membuat". Ketiganya berbeda dalam tujuan dan yang diharapkan adalah hasil-hasilnya. Bagi Aristoteles konteks praksis berarti tindakan reflektif dan memiliki tujuan yang bermanfaat yang dengannya pengetahuan muncul melalui "keterlibatan" dalam situasi sosial. Dalam praksis muncul fronesis yang diartikan sebagai "keadaan yang benar, masuk akal, dan mampu bertindak mengenai hal-hal yang baik atau buruk bagi manusia. Fronesis adalah keadaan pikiran dari mana praksis muncul dan kemudian dikembangkan lagi oleh praksis. Pronesis merupakan kebijaksanan praktis. Sedangkan poiesis adalah cara berhubungan dengan realitas di mana benda konkrit dihasilkan. Hasil tersebut mengandung pengetahuan tertentu dan produksinya melibatkan proses pengetahuan. Ini adalah pengetahuan yang diekspresikan dalam pekerjaan pemahat patung, tukang, pedagang, dan dalam ekspresi yang tinggi, penyair. Praksis

\footnotetext{
${ }^{56}$ Stephen Tong, Iman, Rasio dan Kebenaran (Jakarta: Isntitut Reform, 1996), 19
} 
menunjukkan pada kegiatan membuat yang membutuhkan keahlian. Praksis adalah pengetahuan praktis yang tujuannya adalah tindakan yang terus menerus sedangkan poiesis termasuk tindakan produktif dan beakhir pada apa yang dihasilkan.

Jika yang menimbulkan praksis adalah fronesis maka yang menimbulkan poiesis adalah techne. Melalui techne, cara mengetahui poiesis terjadi, dan penggunaan poiesis mempertajam keahlian atau kemampuan membuat sesuatu didalamnya ada dimensi intelektual yang bersifat reflektif dalam poiesis.Perbedaannya adalah dalam "praksis" pikiran digabungkan dengan melakukan, sedangkan dalam poiesis pikiran dibangun dengan berbuat/membuat. Bagi Aristoteles pendidikan yang dilakukan dengan sengaja harus didasarkan pada cara mengetahui praksis. Ilmu pengetahuan adalah praksis tidak hanya teori. Baginya tujuan pendidikan menciptakan watak moral yang baik bagi warga negara yang siap menghadirkan kesejajteraan negara. Thomas Groome memadukan dialektika antara teori dan praktek.

Kedua, Thomas Groome dengan Hegel dan praksis Geist. Salah tema filsafat Hegel adalah geist. Yang merupakan gabungan dari konsep Yunani tentang akal yang tertinggi serta tradisi Yudeo-Kristiani tentang transenden-imanent. Orang-orang Yunani memahami dunia yang hakikatnya bersifat rasional dan seluruh pengertian tentang rasionalitasnya merupakan sumbangan dari akal yang tertinggi yang adalah sumbernya. Bagi Yunani, akal bukan asas yang aktif dalam proses menjadi, tetapi telah ada di dunia dan dapat dibawa ke kesadaran manusia oleh theoria. Geist adalah asas rasional yang aktif yang mengaktualisasikan dirinya dalam sejarah, bagi Hegel geist adalah bukan kebijaksanaan yang abstrak dan transenden, tetapi akal yang aktif dan tidak terbatas yang mengarahkan dunia dengan pemeliharaannya. Kata-kata Hegel 'adalah benar pemeliharaan, yakni pemeliharaan ilahi, memimpin peristiwa-peristiwa dunia sesuai dengan asas-asas kita, karfean pemelihraan ilahi adalah kebijaksanaan yang diberikan bersama kekuatan yang tidak terbatas yang mewujudkan tujuan miliknya sendiri, yakni tujuan dunia yang final, rasional, dan absolut. Di sini, akal yang lebih tinggi dari filsafat Yunani dan Allah yang efektif, aktif dari pemikiran Yudaisme dan Kristen digabung. Geist adalah akal yang mengaktualisasikan dirinya di dunia. Dalam arti ini, geist bukan saja keadaan tertinggi dan realita, tetapi juga penyebab dunia yang efisien dan utama. Bagi Hegelm geist bergerak maju ke level-level aktualisasi yang lebih tinggi. Hakikat yang sesungguhnya adalah Roh dan tindakan. Roh membuat sendiri apa yang pada dasarnya ada. Roh adalah produk miliknya sendiri, pekerjaan miliknya sendiri. Geist bergerak kea rah aktualisasi diri dengan dinamika batiniah sendiri. Peran manusia hanya melalui kesadaran dan kehendaknya menjadi perantara atau refleksi dari kegiatan aktualisasi diri. Bagi Hegel geist adalah bagian di dalam sejarah manusia. Hegel mendukung teori dan praksisnya menjadi praksis-historis yang merupakan pencarian sumber pengetahuan.

Ketiga, Thomas Groome tentang cara mengetahui praksis dari Karl Mark. Mark menyatakan bahwa kebebasan yang belum direalisasikan oleh proses evolusioner yang dicita-citakan adlah bukan kebebasan sama sekali. Mark menola geist dari Hegel yang hanyalah suatu ketakjuban dalam alam pikir. Bagi Mark pengetahuan bersifat gagasan sekarang menjadi proses menusia dan historisnya. Bagi Mark pengetahuan buka refleksi dari geist melainkan refleksi dari materialism historis yakni kondisi-kondisi kehidupan materil, dan khsusnya bagaimana memproduksi benda yang diwujudkan masyarakat dan sejarah. Dalam epistemologinya Mark memadang kerja sebagai perantara antara subjek dan objek, kerja tidak hanya cara terlibat dalam dunia, kerja adalah juga cara mengetahui dunia, melalui pengetahuan. Mengetahui dunia melalui reflektif kritis dan mengubah dunia. 
Keempat, Thomas Groome dengan Paulo Freire dengan praksis pendidikannya. Freire memulai pendidikan dari praksisnya. Ia mengajar orang-orang untuk membaca paling sedikit enam minggu. Suatu emansipasi menurut Groome. Ada tiga asumsinya, pertama, humanisasi adalah panggilan utama manusia, kedua orang-orang harus mampu mengubah realitas mereka, menciptakan kebudayaan mereka. Ketiga, pendidikan tidak pernah netral, pendidikan selalu ada konsekuensinya secara politik. Bagi Freire pendidikan harus membebaskan untuk mencapai hal itu ia mengusulkan model pemecahan masalah, sebagai refleksi kritis dan membuka mite-mite yang menipu dan mengabaikan.

Dalam usaha ketekese yang paling awal membawa pemikiran bahwa gaya hidup yang diperbaharui Roh Kudus dan firman adalah jalan menuju keselamatan dan kehidupan yang bermoral di dunia. Augustinus dari aliran Alexandaria, menekankan the city of God dan connesions adalah refleksi spritualitas atas relasi pribadi dengan Tuhan. Tujuan teologisnya adalah pencarian kebijkasanaan spiritual dan praktis. Thomas Aguinas sangat menekankan pentingnya peran kecerdasarn dalam proses pengetahuan, dengan metodenya yang diperluas dari theoria. Dimana tidak ada jalan menuju kecerdasan jika tidak dimulai dari pengalaman indera-indera yang bersifat reflektif dan ia menyebutnya sebagai summa.

Memang Marti Luther menolak intelektual dari penganut skolastika yang mencoba mencari Allah dari rasionalitas manusia. Bagi Luther menekankan iman sebagai bentuk kepercayaan kepada Allah dibanding dengan dalil-dalil yang doctrinal. Bagi Groome faktor pengalaman bersama Allah di dunia tidak bisa diabaikan dalam berbagai kehidupan, termasuk dalam pendidikan. Allah adalah penguasa seluruh kehidupan termasuk dalam dunia pendidikan, maka siapapun yang mau taat dan menyembahnya dalam seluruh lapangan kehidupan pastilah mengalami pemeliharaan dan pertolongan Allah.

\section{KESIMPULAN}

Filsafat PAK didasarkan pada teologi yang alkitabiah, dimana firman Tuhan yang tertulis dalam Alkitab menjadi tolak ukur dalam berfilsafat secara kristiani. Teologi sistematik merupakan formula yang baik dalam mengembangkan prinsip dan praksis filsafat pendidikan Kristen. Otoritas firman secara tertulis yaitu Alkitab dan firman yang menjadi daging atau manusia dalam diri Yesus Kristus harus memengaruhi setiap gaya berpikira dan tata laku dari praksis pendidikan.

Fondasi filosofis pendidikan kristiani mencakup tiga unsur utama yang juga menjadi perhatian serius dalam menjalankan pendidikan dan proses pembelajaran yaitu pada unsur metafisika, epistemologi dan aksiologi.

Dalam dinamika dan pengembangan pendidikan kristiani tidak bisa mengabaikan dan bahkan memisahkan antara ilmu dan iman. Pendidikan Kristen memadukan atau mengintegrasikan antara iman dan ilmu pengetahuan, dimana rasio menjadi hal penting bagi pengembangan ilmu pengetahuan dan iman sebagai dasar dalam melakukannya. Rasio harus tunduk pada otoritas firman Tuhan dan iman mendorong untuk menerima dan mempercayai hal-hal yang ada di dalam, lebih dan atau di luar dari nalar manusia. Dengan demikian kita menemukan korelasi landasan teologis dan filosofis perumusan dan pengembangan Prinsip dan Praksis Pendidikan Agama Kristen. 


\section{Referensi}

Anthony, Michael J., Edited \& Writen, Foundation of Ministry An Introduction to Christian Education For A New Gereration,. Malang: Gandum Mas. 2012.

Berkhof, Louis dan Chornelius Van Til, Foundation of Christian Education, terjemahan ketiga. Surabaya: Momentum, 2010.

Bilo, Dyulius Thomas, Bahan Ajar: Filsafat Pendidikan Agama Kristen. Jakarta: STT SETIA, 2018.

Braley, James, Jack Layman, and Ray White, Foundation of Chritian School Education. Colorado Springs: Purposeful Design, 2003.

Brown, Colin, Philosophy and the Christian Faith. London: InterVarsity, 1973.

Butler, J. Donald, Four Philosophies and Their Practice in Education and Religion. New York:Herper\&Row, 1968.

Chaffee, John, The Philosopher's Way, third edition. Boston:Pearson, 2011.

DeJong, Norman, Education in the Truth. Nutley, NJ: Presbyterian\&Reformed, 1974.

Geisler, Norman L. dan Paul D. Feinberg, Filsafat Dari Perpektif Kristiani. Malang: Gandum Mas, 2002.

Holmes, Arthur F., ed.., The Making of a Christian Mind: A Christian World View and the Academic Enterprise. Downer Grove, IL: InterVasity, 1985.

Kattsoff Lois O., Pengantar Filsafat. Yogyakarta: Tiara Wacana Yogya, 2004.

Knienel, Paul A., Gibbs Ollie E. and Berry Sharom E, editors, Philosophy of Christian School Education. Colorado: ACSI Publisher, 1982.

Knight, George R., Philosophy and Education An Introduction in Christian Prespective. (Berrien Springs, MI: Andrews University Press, 1980.

Kolibu, Dirk Roy, Bahan Ajar: Teologi Pendidikan Agama Kristen. Jakarta: Pascasarjana UKI, 2020.

Manson, Charlotte, Home School Education,Home Education Series Vol.8,edisi 6. Oxford:Scrivener, 1953.

Pazmino, Robert W., Fondasi Pendidikan Kristen. Jakarta: BPK. Gunung Mulia, 2012.

Rapar, Jan Hendrik, Pengantar Filsafat. Yogyakarta: Penerbit Kanisius, 1996.

Richrads, Lawrance O., A Theology of Christian Education. Grand Rapid, Michigan: Zondervan Publishing House, 1975.

Sadulloh, Uyoh, Pengantar Filsafat Pendidikan. Bandung: Alfabeta,2008.

Tong, Stephen, Iman, Rasio dan Kebenaran. Jakarta: Isntitut Reform, 1996.

Tung, Khoe Yao, Filsafat Pendidikan Kristen: Meletakkan Fondasi dan Filosofi Pendidikan Kristen di Tengah Tantangan Filsafat Dunia. Yogyakarta: Andi,2013. 